Mycologia, 96(5), 2004, pp. 1152-1154.

(C) 2004 by The Mycological Society of America, Lawrence, KS 66044-8897

\title{
Bovista sclerocystis, a new species from Mexico
}

Francisco D. Calonge ${ }^{1}$

Real Jardín Botánico, CSIC, Plaza de Murillo, 2. E28014 Madrid, Spain

Hanns Kreisel

Zur Schwedenschanze, 4 D-17498, Potthagen, Germany

\section{Gastón Guzmán}

Instituto de Ecología, $\mathrm{km} 2.5$ antigua carretera a Coatepec, Apartado Postal 63, Xalapa, Veracruz, 91000, Mexico

Abstract: Bovista sclerocystis is described as a new species. It was found in Mexico, growing on rich soil of a tropical forest. It belongs to section Globaria, series Albosquamosa. The most striking character of this taxon is the exoperidium composed of polymorphous mycosclereids.

Key words: Gasteromycetes, Lycoperdaceae, tropical fungi

The genus Bovista Pers.: Pers. was monographed by

\footnotetext{
Accepted for publication October 22, 2003.

${ }^{1}$ Corresponding author. E-mail: calonge@ma-rjb.csic.es
}

Kreisel (1967), who included 46 species. Kreisel and Calonge (1996) later combined Lycoperdon septinum Lloyd with B. septina (Lloyd) Kreisel \& Calonge, a member of the B. colorata (Peck) Kreisel complex. In the course of a revision of the Gasteromycetes preserved at the herbarium of the Instituto de Ecología, Xalapa, Mexico (XAL), we were able to study a collection of the proposed taxon, composed of 20 mature basidiomata. Morphological and anatomical characters differentiate this taxon from all previously described species in the genus.

Samples were prepared for microscopy using 5\% $\mathrm{KOH}$ as mounting medium before viewing with a Nikon Lapophot 104 light microscope. Ultramicroscopy was carried out after gleba samples were coated in gold with a Balzers SCD 004 sputter coater, using a JEOL JSM-T330A scanning electron microscope.

Bovista sclerocystis Calonge, Kreisel \& Guzmán, sp. nov. Figs. 1-3

Etymology. sclerocystis, due to the presence of mycosclereids in the exoperidium.

Basidiomata globosa, 10-20 mm diam, basi rhizomorphis subalbidis adnata.

Exoperidium ochraceo-brunneum, equaliter dense
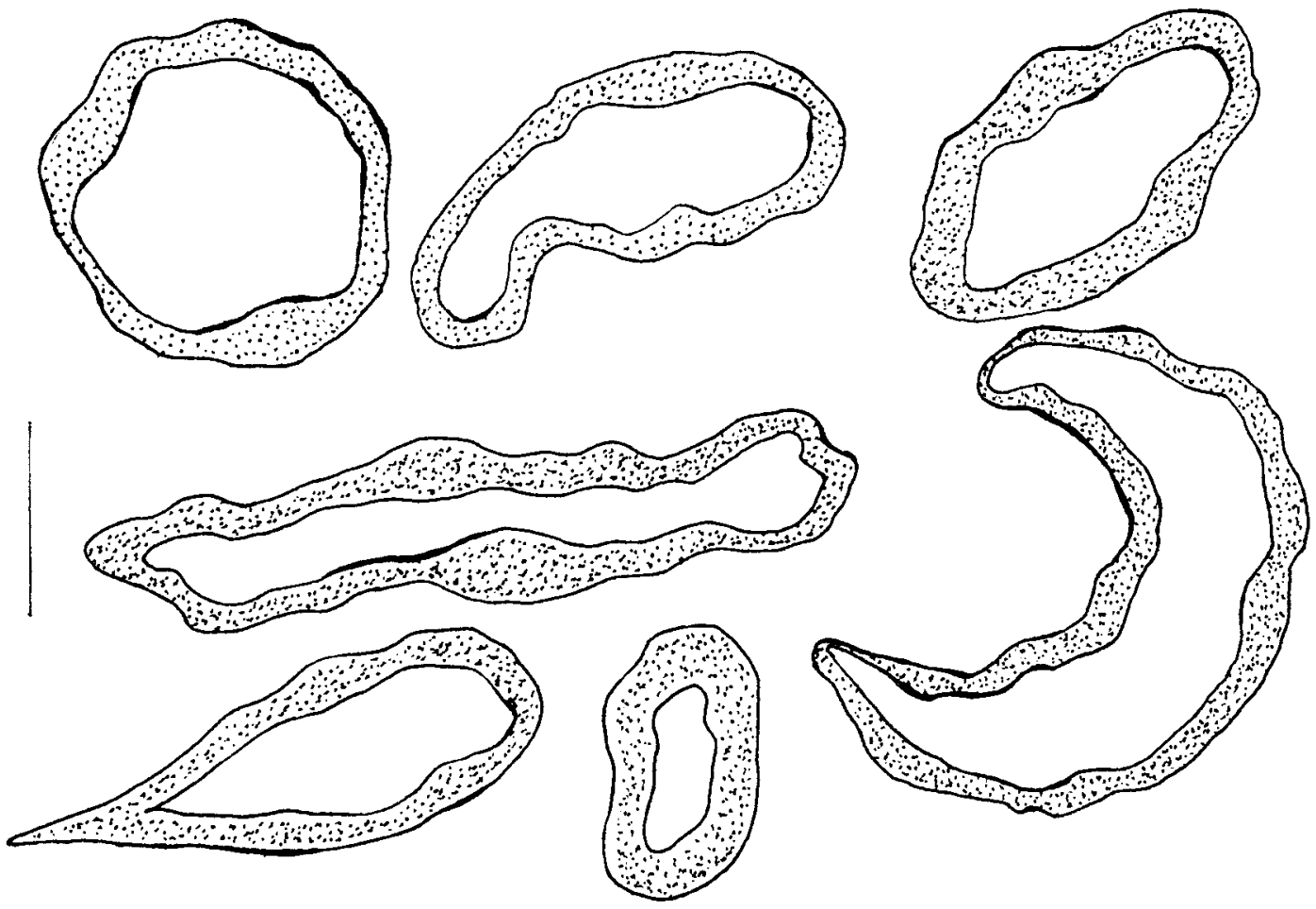

FIG. 1. Bovista sclerocystis. Variable morphology of the mycosclereids. Scale bar $=10 \mu \mathrm{m}$. MA-Fungi 34355. 

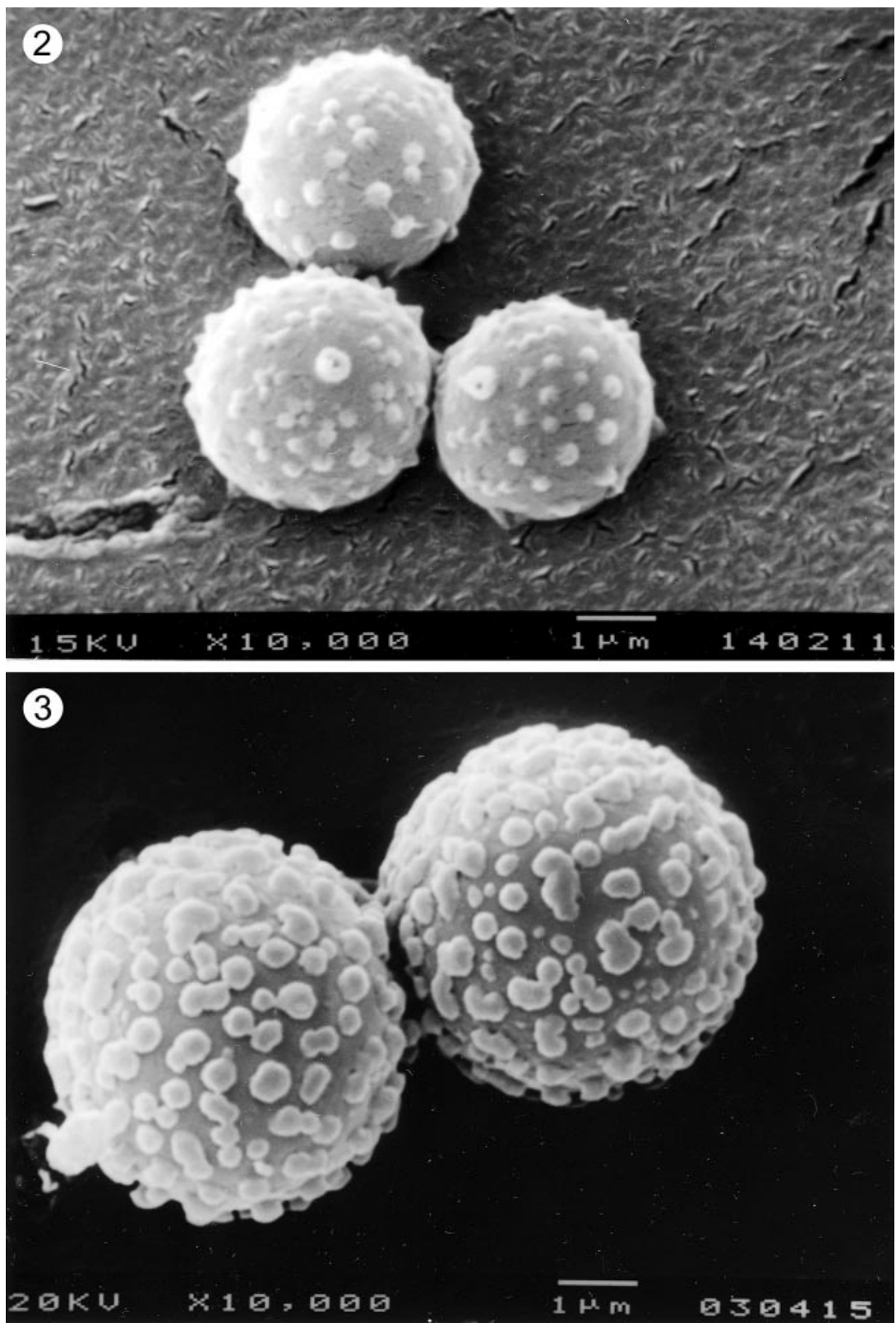

FIG. 2. Bovista sclerocystis. Spores as seen under SEM. Observe the fine ornamentation made of small pyramidal warts, up to $0.3 \mu \mathrm{m}$ high. Scale bar $=1 \mu \mathrm{m}$. XAL, G. Carrión 823.

FIG. 3. Bovista septina. Spores observed under SEM showing a larger size and the ornamentation made of cylindrical warts. Scale bar $=1 \mu \mathrm{m}$. MA-Fungi 34355 .

granulosum vel verrucosum. Verrucae et cellulis mycosclereidis multiformibus, crassae tunicatis, ad 42 $\mu \mathrm{m}$ longis, compositae. Endoperidium brunneolum, tenuiter papyraceum, cum orificio apicali irregulari. Gleba matura pulverulenta, floccosa, brunneola tabacina. Sporae globosae, 3.3-4.0 $\mu \mathrm{m}$ diam, brunneolae, glabrae ad punctatae sub microscopio optico, verruculosae sub SEM, haud pedicellatae. Capillitium modo transitorio ramificatum dichotomicum. Hyphae brunneae, subelasticae, non perforatae, non septate, ad $5 \mu \mathrm{m}$ crassae. Paracapillitium abundans, hyalinum. Habita ad terram in silvis tropicalibus, MEXICO, CHIAPAS: Ocozocoautla, Reserva Naturali El Ocote, 15 Feb 1986, G. Carrion 823 (XAL-HOLOTYPUS).

Fruit bodies globose, 10-20 mm diam, base with rudimentary pseudostipe and ramified whitish rhizomorphs. Exoperidium ochraceous-brown, forming equal fine warts or granules, composed of polymorphous mycosclereids (FIG. 1) which are globose, 12$30 \mu \mathrm{m}$ diam, ovoid, ellipsoid, claviform, or irregular, 
$15-42 \times 12-15 \mu \mathrm{m}$, with cell walls $1-7 \mu \mathrm{m}$ thick. Endoperidium thin, papery, ochraceous to brownish, dull to slightly shining, with an apical aperture of irregular outline, 1-6 mm diam. Gleba ochraceous, grayish brown, powdery floccose. Subgleba absent. Spore deposit when mature grayish brown, without olivaceous tints.

Spores globose, 3.3-4.0 $\mu \mathrm{m}$ diam, smooth to punctate under LM, brownish, verruculose under the SEM, with pyramidal warts less than $0.3 \mu \mathrm{m}$ high (FIG. 2), apedicellate with a rest of sterigma up to 1 $\mu \mathrm{m}$ long, hyaline. Broken fragments of sterigmata scarce, hyaline, up to $6 \times 1 \mu \mathrm{m}$, which can be visible in water mounts. Capillitium $2-5 \mu \mathrm{m}$ diam, of transitory type, with few dichotomous branches, which indicate it well could be of Lycoperdon type, brownish, subelastic, moderately thick-walled, not pitted, neither septate. Paracapillitium 2-4 $\mu \mathrm{m}$ diam, abundant, hyaline, incrusted, asperulate.

Specimen examined. MEXICO, CHIAPAS: Ocozocoautla, Natural Reserve El Ocote, 15 Feb 1986, G. Carrión 823 (XAL-HOLOTYPE), (MA-Fungi 52379ISOTYPE).

From the taxonomical point of view, B. sclerocystis is related closely to B. septina (Lloyd) Kreisel \& Calonge, known from Ecuador and Venezuela (Kreisel and Calonge 1996), but is distinguished by having a compact subgleba, larger fruit bodies $(20-30 \mathrm{~mm}$ diam), darker gleba (chocolate-black), with an almost black spore deposit, larger and more distinctly ornamented spores, with cylindrical warts up to $0.5 \mu \mathrm{m}$ high (FIG. 3) and by its habitat at 4000-4500 m. Both B. sclerocystis and B. septina belong to section Globaria, series Albosquamosa (Kreisel 1967). Bovista abyssinica Mont. also is related closely to B. sclerocystis but has a compact subgleba, olive brown capillitium without pores and pseudosepta but with spiny exoperidium without mycosclereids, growing on high mountains of tropical Africa (Kreisel 1967, 2001). The presence of mycosclereids in the exoperidium of B. sclerocystis is a unique character in Bovista, while it is rather common in the genus Tulostoma (Wright 1987). Thus, this character, together with the almost smooth globose spores, capillitium of transitory type without pores or septa, abundant, hyaline, incrusted, asperulate paracapillitium, lack of subgleba and ecology, add up to a combination of features that differentiate this taxon from all previously described within Bovista.

\section{ACKNOWLEDGMENTS}

This work was supported by a grant to Prof. F.D. Calonge from the Spanish Ministry of Education. We are grateful to Dr María P. Martín for useful comments on the text, to Florencia Ramírez-Guillén, curator of XAL, for her valuable help, and to Miguel Jerez, for technical assistance with SEM.

\section{LITERATURE CITED}

Kreisel H. 1967. Taxonomich-pflanzengeographische Monographie der Gattung Bovista. Beih. Nova Hedwigia 25: $1-244$.

. 2001. Checklist of the gasteral and secotioid Basidiomycetes of Europe, Africa and Middle East. Österr. Z. Pilzkunde 10:213-313.

, Calonge FD. 1996. Bovista septina (C.G. Lloyd) Kreisel \& Calonge comb. nov. Bol. Soc. Micol. Madrid 21: 393-394.

Wright JE. 1987. The genus Tulostoma (Gasteromycetes). A world monograph Bibliotheca Mycol. 113:1-338. 